\title{
BioéthiqueOnline
}

\section{Disability is in the Eye of the Beholder}

\section{Frank Verpaelst}

Volume 4, 2015

Reçu : 20 Feb 2015; publié : 26 Mar 2015; éditeurs : Vincent Couture \& Hadi Karsoho

URI : https://id.erudit.org/iderudit/1035495ar

DOI : https://doi.org/10.7202/1035495ar

Aller au sommaire du numéro

Éditeur(s)

BioéthiqueOnline

ISSN

1923-2799 (numérique)

Découvrir la revue

Citer cet article

Verpaelst, F. (2015). Disability is in the Eye of the Beholder. BioéthiqueOnline, 4. https://doi.org/10.7202/1035495ar
Résumé de l'article

Je suis atteint de nanisme et je blogue principalement sur les questions liées au handicap. Ce récit porte sur mes impressions à propos de l'étiquette " handicapé ". d'utilisation que vous pouvez consulter en ligne. 


\title{
Disability is in the Eye of the Beholder
}

\author{
TRAVAIL CRÉATIF / CREATIVE WORK \\ Frank Verpaelst ${ }^{1}$
}

Reçu/Received: 20 Feb 2015

Éditeurs/Editors: Vincent Couture \& Hadi Karsoho

Publié/Published: 26 Mar 2015

2015 F Verpaelst, Creative Commons Attribution 4.0 International License

Résumé

Je suis atteint de nanisme et je blogue principalement sur les questions liées au handicap. Ce récit porte sur mes impressions à propos de l'étiquette « handicapé ».

Mots clés

nanisme, politiques de santé, handicap, incapacité
Summary

I have dwarfism and blog mainly about disability related issues. This story expresses my feelings about the label "disabled".

\section{Keywords}

dwarfism, health care policy, handicap, disability

Affiliations des auteurs / Author Affiliations

${ }^{1}$ Montréal, Canada

\section{Correspondance / Correspondence}

Frank Verpaelst, frank_verpaelst@yahoo.com

\section{Conflit d'intérêts}

M. Verpaelst est un ami de Maude Laliberté, éditrice de section de BioéthiqueOnline; Mme Laliberté n'a pas été impliquée dans l'évaluation de ce manuscrit.

\begin{abstract}
Conflicts of Interest
M. Verpaelst is a friend of Maude Laliberté, Section editor at BioéthiqueOnline; Ms Laliberté was not involved in the evaluation of this manuscript.
\end{abstract}

\section{Preamble}

I have dwarfism, and have been blogging (http://www.patreon.com/gutsydwarf), mainly about disability related issues and have been a guest several times now on various CBC radio shows. This story expresses my feelings about the label "disabled".

\section{Disability is in the Eye of the Beholder}

To be blunt about it, I very much dislike words like "disabled" and "handicapped". For several years now, I've maintained that disability is in the eye, and mind, of the beholder. The reality is, every single human being on the planet has a wide range of abilities and limitations, which are constantly in a state of flux. A well balanced and positive individual wakes up every day, and focuses on what they CAN do, instead getting hung up on their limitations.

And while I totally support the notion of believing in oneself, and having dreams, I also understand that delusion is not a good thing. Having been born with dwarfism, I totally accept that in all likelihood, I will never be a professional athlete. But should I let that stop me from participating in the sports that I love, out of self-doubt and fear? Never!

When you focus on your abilities, it opens a world of possibilities. For instance, I never played Lacrosse, but I loved the sport. Instead of whining about it, I decided to get involved, and coached a peewee team: Truly the most exciting days of my life! I also loved playing table tennis, but could never win a game against my taller friends. So, I joined a local club, and signed up for a summer time training camp. Although I never won a match in any of the tournaments, when I got back to college that autumn, my friends sure were surprised when those Ping-Pong balls started whipping past them. 
At a certain point in my life, I stopped heaping blame on my shoulders because I could no longer walk up a flight of stairs. Was I really disabled, or, was the entire construction business "design challenged"? With all those civil engineers, architects, and inventors in the world, and billions of dollars spent on new homes and condos throughout the world, are you telling me that absolutely no one can invent an inexpensive and safe way to get grandpa up the stairs? In my opinion, we are not disabled, it's the rest of society that is lacking the moral fibre to make our world fully accessible.

Labels are linguistic constructs that help classify and streamline the objects and ideas that surround us. But here's an experiment that could show how even objects are limited by labels. Consider a chair: In the eyes of an adult, a chair is a chair, and nothing more. But is it truly just a chair? Place a chair in the middle of a room, surrounded by a few simple toys. Bring a child into that room, and back away, leaving the child to interact with those toys, and that chair. I guarantee you that chair will become something else in the imagination of most children. It will become a mountain, a castle, a fort, a monster. That chair will cease to exist, as it travels through the optic nerve, and is magically transformed in the magical mind of that child.

Imagine, further, if architects and home builders thought "multipurpose entrance", instead of "doors, stairs, and ramps". How much more flexible would their constructs be, and how more fluidly would we all move about our daily business, even those of us who society labels "disabled"?

Labels can be useful, especially with regards to our rights and having programs made available to persons with disabilities. However, we must always be aware of the double-edged swords that labels represent: We might have a certain disability, but we should never let that disability define who we are, or limit who we can become. When we look at each other, rather than focusing on disability, or any other labels that have been applied to us, wouldn't it be better if we all focused on each other's abilities and potential?

\section{Post Script}

As evidence of this power to positively (or negatively) affect another individual's potential, I encourage you to listen to this podcast - How To Become Batman - which tells the story of a blind man who says expectations have helped him see. 